\title{
THE EFFECT OF RESEARCH AND DEVELOPMENT (R\&D) EXPENDITURES ON EXPORT: EVIDENCE FROM A PANEL OF SELECTED OECD COUNTRIES
}

\author{
DOI: 10.17261/Pressacademia.2018.932 \\ JEFA- V.5-ISS.3-2018(1)-p.234-241
}

\author{
Yasemin Dumrul ${ }^{1}$, Zerrin Kilicarslan ${ }^{2}$ \\ ${ }^{1}$ Erciyes University, Develi Hüseyin Şahin Vocational School, Office Management and Secretary, Kayseri, Turkey. \\ ydumrul@erciyes.edu.tr, ORCID: 0000-0001-5961-2931 \\ ${ }^{2}$ Erciyes University, Kayseri Vocational School, Kayseri, Marketing and Foreign Trade, Kayseri, Turkey. \\ zkaan@erciyes.edu.tr, ORCID: 0000-0002-0905-3067
}

Date Received: June 29, 2018

Date Accepted: September 2, 2018

To cite this document

Dumrul, Y., Kilicarslan, Z. (2018). The effect of research and development (R\&D) expenditures on export: evidence from a panel of selected OECD countries. Journal of Economics, Finance and Accounting (JEFA), V.5(3), p.234-241.

Permemant link to this document: http://doi.org/10.17261/Pressacademia.2018.932

Copyright: Published by PressAcademia and limited licenced re-use rights only.

\section{ABSTRACT}

Purpose- R\&D activities help countries to gain competitive power and thus achieve economic growth. The purpose of this paper is to analyze the effect of R \& D activities on exports for 16 OECD countries using data from the period 2000-2015.

Methodology- Pedroni (1999) and Kao (1999) panel cointegration tests were used to test whether there is a long-term relationship between variables. In order to be able to do the cointegration analysis, the stationary of the variables considered should be determined. The unit root examination is conducted using four unit root tests; namely, the Levin, Li and Chu; Im, Pesaran and Shin W-stat; Fisher-ADF and Fisher-PP. Panel FMOLS and DOLS estimators were used to obtain long run coefficients after the cointegration relation was detected. Findings- As a result of Pedroni and Kao cointegration test, it has been found that there is a long term relationship between $R$ \& $D$ expenditures and exports. Both Panel FMOLS and Panel DOLS test results show that the sign of R \& D expenditures is positively and statistically significant. According to the Panel FMOLS test results, a $1 \%$ increase in R \& D expenditures leads to a $0.45 \%$ increase in exports. Similarly, according to Panel DOLS test results, $1 \%$ increase in R \& D expenditures increases exports by $0.43 \%$.

Conclusion- The results showed that the effect of R \& D expenditures on exports is positive. Results obtained in the study are consistent with existing findings in the literature.
\end{abstract}

Keywords: R\&D expenditures, export, panel co-integration test, panel FMOLS, panel DOLS.

JEL Codes: F14, O30, C23

\section{INTRODUCTION}

Research and development ( $R \& D$ ) activity can be defined as the creation and development of new products based on knowledge and technology and the realization of new production techniques (Güzel, 2009: 31). On the one hand, R \& D activities increase the capacity of the country to produce new technology and thus to develop new products, and on the other hand speed up the spread of technology among countries and / or sectors (Şahbaz et al., 2014: 49). R \& D activities not only affect the efficiency of the firm that makes these activities, but also increase the efficiency of other firms with its spillover effects (Pradeep et. al., 2017: 19). Thus, R \& D activities help countries to increase their exports to gain competitive power and thus to provide economic growth (Akiş, 2015: 1314-1319)

As the investment in R \& D increases, goods or services become more innovative and competitive in international markets, thus creating a competitive advantage that has positive effects on countries' exports (Neves et al., 2016: 130; Yüksel, 2017: 2). In addition to its competitive advantage, $R \& D$ activities have advantages for countries in attracting foreign capital, increasing productivity and getting rid of technological dependence (Güzel, 2009: 30). However, countries may not be able to benefit from some of the benefits of R\&D activities, for various reasons such as imitation, job change of personnel, intercompany cooperation, which may lead to diffusion effects (Svensson, 2008: 12). 
The purpose of this study, the effect of R \& D activities on exports, which is selected for OECD countries including Turkey is examined for the 2000-2015 period. In the studies conducted in the literature, different variables such as R \& D expenditures, number of patents, patent expenditures, $R$ \& $D$ stock $^{1}$ and $R$ \& $D$ personnel were used as indicators of $R$ \& $D$ activities. In this study, the effect of $R$ \& $D$ activities on exports is examined using $R$ \& $D$ expenditures as a indicators of $R$ \& $D$ activities. The plan of this paper is as follows: in the next section, the relationship between $R \& D$ activities and exports is theoretically revealed. In the third section, a empirical literature summary related to the subject is presented. In the fourth section, information about the methodology, the applied model, the data used in the study and are given. In the fifth section, panel unit root tests, panel cointegration tests and panel FMOLS and DOLS test results, which are applied in the study, are included. In the last section, the conclusion and evaluations related to the study are given.

\section{THEORETICAL FRAMEWORK}

Countries develop their technology by conducting R \& D activities in order to increase their competitiveness and ensure economic growth. Technology has been accepted as an endogenous variable in some of the theories in economics literature and as an exogenous variable in some of them. In classical and neoclassical trade theories, technology is considered as an exogenous variable, but the nature of technological developments, their reasons, how they emerge and the factors that affected them have not been taken into consideration (Özer and Çiftçi, 2009: 39). The inclusion of technology as an internal variable to the trade theories first occurred with "The Product Cycle Theory" and "Technology Gap Theory". According to these theories, the main factor determining foreign trade is the technology differences between countries. In this context, the fact that countries are profitable from foreign trade and they are able to achieve sustainable growth rates depends on their ability to produce and / or transfer new technology (Şahbaz et al., 2014:48; Yıldırım and Kesikoğlu, 2012:166). According to Vernon (1966), technology development is emerging in countries where skilled labor and R \& D expenditures are high (Yıldırım and Kesikoğlu, 2012:166). In the endogenous growth theories based on Schumpeter, the technology created by R \& D activities is accepted as an endogenous variable (Şahbaz et al., 2014: 48). According to Schumpeter; in free-market economies where competition is high, either companies will constantly renew themselves and develop new products and production processes, or they will be wiped out of the market (Göçer, 2013a: 218). However, according to theories of endogenous growth, investments in R \& D can lead to long-term growth and increased returns to scale (Svensson, 2008: 11).

There is a complementarity relationship between $R \& D$ and exports. This relationship is caused by two reasons. The first is the increase in exports with knowledge accumulation obtained through endogenous $R$ \& $D$ activities. When countries create innovation as a result of $R \& D$ activities, they use these innovations not only to meet domestic demand but also to meet foreign demand through export (Özer and Çiftçi, 2009: 41). Thus, the production and export made to meet the foreign demand is increasing.

In the literature, there is a general consensus on the extent to which R \& D activities increase exports (Girma et al., 2008: 752; Esteve-Pérez and Rodríguez, 2013: 221). In addition to increasing exports of R \& D activities, the size of R \& D expenditures also causes the volume of foreign trade to increase and qualitatively change. For example, foreign trade shifts from low and medium technology products to high technology products (Çetin, 2016: 35).

The second is that exports have a positive influence on $R \& D$ and export experience creates innovation flows that increase firms' innovative capacities and R \& D activities (Esteve-Pérez and Rodríguez, 2013: 221; Neves et al.,2016: 132). Therefore, it is necessary for exporters to invest in new technology to compete in international markets and to meet the demands of a more sophisticated demand (Girma et al., 2008: 751). The increase in R \& D and innovation through exports is called "learning by exporting" by Hobday (1995). According to this view, export are positively affects the technological and innovative capacity of firms (Neves et al.,2016: 131). In other words, domestic companies that have innovative, differentiated products and use the latest technology are able to export their products more easily. In addition, exporters compete in export markets and thus investing by becoming aware of foreign Technologies (Girma et al., 2008: 750). However, production for a wider market reduces the unit costs of R \& D investments and encourages these activities (Özer and Çiftçi, 2009: 41). R \& D and exports complement each other in terms of increasing knowledge, decreasing costs and increasing profits of firms (Neves et al.,2016: 132). At the same time, innovations emerging as a result of R \& D activities have given monopoly power to the firm that created it, at least for a certain period of time (Özer and Çiftçi, 2009: 41).

\footnotetext{
${ }^{1} \mathrm{R} \& \mathrm{D}$ stock is calculated by considering the $\mathrm{R} \& \mathrm{D}$ investment (RDE), the depreciation rate $\delta$ ) and the R \& $\mathrm{D}$ investment increase rate (g). $R D S_{0}=\frac{R D E}{g+\delta}$
} 


\section{BRIEF LITERATURE REVIEW}

In applied studies in the literature related to the subject, various variables such as R \& $D$ expenditures, number of patents, patent expenditures, $R$ \& $D$ stock and $R$ \& $D$ personnel have been used as indicators of $R$ \& $D$ activities. $R$ \& $D$ expenditures have been used as an indicator of $R \& D$ activities in many studies, because of the ease and reliability of data collection (Sungur et al., 2016: 175). Table 1 presents the studies that take into account R \& D expenditures as a demonstration of R \& $D$ activities. As shown in Table 1, the majority of studies have reached the conclusion that $R \& D$ activities have a positive effect on exports. However, Landesmann and Pfaffermayr (1997) found a negative relationship between R \& D expenditure and exports in Germany and France. According to Landesmann and Pfaffermayr (1997) the reason for the negative relationship between the two variables is that the increase in $R$ \& $D$ expenditures leads to decreasing returns and improvements in productivity or product quality are compensated by higher wage demands (Landesmann and Pfaffermayr,1997: 196).

Table 1: Summary of Empirical Studies Relationship between R\&D Activities and Export

\begin{tabular}{|c|c|c|c|}
\hline Author & Period / Country & Method & Results \\
\hline Türker (2018) & $\begin{array}{l}2000-2015 \\
\text { G- } 7 \text { countries }\end{array}$ & $\begin{array}{l}\text { Panel data analysis (Panel } \\
\text { OLS) }\end{array}$ & $\begin{array}{l}\text { According to the results of this study, there is a } \\
\text { positive relationship between R\&D expenditures } \\
\text { and exports. The increase (decrease) in R \& D } \\
\text { expenditures increases (reduces) exports. }\end{array}$ \\
\hline $\begin{array}{l}\text { Özkan and Yılmaz } \\
\text { (2017) }\end{array}$ & $\begin{array}{l}\text { 1996-2015 } \\
12 \text { EU countries } \\
\text { and Turkey }\end{array}$ & Panel data analysis & $\begin{array}{l}\text { The conclusion of the study shows that } R \& D \\
\text { expenditures positively affect high technology } \\
\text { exports and GDP. The results show that a } 1 \% \\
\text { increase in R \& D expenditures leads to a } 3.5 \% \\
\text { increase in high tech exports. }\end{array}$ \\
\hline Çetin (2016) & $\begin{array}{l}1996-2013 \text { new } \\
7 \\
\text { industrialized } \\
\text { countries }\end{array}$ & $\begin{array}{l}\text { Panel data analysis, } \\
\text { Granger causality test, } \\
\text { (fixed and random effects } \\
\text { estimation methods) }\end{array}$ & $\begin{array}{l}\text { The results of the Granger causality test show } \\
\text { that } R \& D \text { expenditures lead to the export of } \\
\text { high-tech products, while random effects } \\
\text { estimation shows that } R \& D \text { expenditures } \\
\text { positively and significantly affect high-tech } \\
\text { product exports. }\end{array}$ \\
\hline $\begin{array}{l}\text { Sungur et al. } \\
(2016)\end{array}$ & $\begin{array}{l}\text { 1990-2013 } \\
\text { Turkey }\end{array}$ & $\begin{array}{l}\text { Engle-Granger } \\
\text { cointegration test, Granger } \\
\text { and Hatemi-J asymmetric } \\
\text { causality test }\end{array}$ & $\begin{array}{l}\text { According to Granger Causality test results, } \\
\text { unilateral causality relation exists from export to } \\
\text { share of R\&D expenditures in GDP, from patents } \\
\text { to export and from R\&D labor force to export. } \\
\text { According to Hatemi-J asymmetric causality } \\
\text { analysis reslts, there is a bidirectional relation } \\
\text { between positive components of R\&D labor and } \\
\text { export; and there is a relation between negative } \\
\text { components from R\&D labor to export and from } \\
\text { export to R\&D. }\end{array}$ \\
\hline $\begin{array}{l}\text { Sandu and } \\
\text { Ciocanel (2014) }\end{array}$ & $\begin{array}{l}2008-2010 \\
26 \text { EU countries }\end{array}$ & Panel data analysis & $\begin{array}{l}\text { This study shows that a } 1 \% \text { increase in public } \\
\text { sector } R \& D \text { expenditures has increased } 8 \% \text { of } \\
\text { high-tech exports } 2 \text { years later and a } 1 \% \text { increase } \\
\text { in private sector } R \& D \text { expenditures has } \\
\text { increased } 9 \% \text { of high-tech exports in the same } \\
\text { year. }\end{array}$ \\
\hline $\begin{array}{l}\text { Kılıç et al. } \\
\text { (2014) }\end{array}$ & $\begin{array}{l}\text { 1996- } 2011 \\
\text { G-8 countries }\end{array}$ & Panel data analysis & $\begin{array}{l}\text { In this study, it has been determined that R \& D } \\
\text { expenditures have a positive effect on high-tech } \\
\text { product exports. It is also found that there is } \\
\text { bidirectional causality between R \& D } \\
\text { expenditures and high-tech product exports. }\end{array}$ \\
\hline Göçer (2013a) & $\begin{array}{l}\text { 1996-2012 } \\
11 \text { Asia countries }\end{array}$ & $\begin{array}{l}\text { Hadri-Kuruzomi unit root } \\
\text { test, Dumitrescu-Hurlin } \\
\text { test, Westerlung-Edgerton } \\
\text { LM bootstrap test }\end{array}$ & $\begin{array}{l}\text { This study shows that R \& D expenditures } \\
\text { increase } \\
\text { information-communication } \\
\text { technologies exports and general exports. }\end{array}$ \\
\hline Göçer (2013b) & $\begin{array}{l}\text { 1996-2012 } \\
\text { New Industrialized } \\
\text { Countries }\end{array}$ & $\begin{array}{l}\text { Pedroni cointegration test, } \\
\text { Panel Fisher test }\end{array}$ & $\begin{array}{l}\text { The study concludes that there is a positive } \\
\text { relationship between R \& D expenditure and } \\
\text { high-tech product exports. }\end{array}$ \\
\hline
\end{tabular}




\begin{tabular}{|c|c|c|c|}
\hline $\begin{array}{l}\text { Yıldırım and } \\
\text { Kesikoğlu (2012) }\end{array}$ & $\begin{array}{l}\text { 1996-2008 } \\
\text { Turkey }\end{array}$ & $\begin{array}{l}\text { Panel causality test, GMM } \\
\text { and Wald test }\end{array}$ & $\begin{array}{l}\text { This study shows that there is a one-way } \\
\text { causality relationship from } R \& D \text { expenditure to } \\
\text { exports and export does not cause R\&D } \\
\text { expenditure. }\end{array}$ \\
\hline $\begin{array}{l}\text { Uzay et al. } \\
(2012)\end{array}$ & $\begin{array}{l}1995-2005 \\
40 \text { countries with } \\
\text { the highest export } \\
\text { in Turkey }\end{array}$ & Panel data analysis & $\begin{array}{l}\text { In this study, there is a positive relationship } \\
\text { between } R \& D \text { expenditures and exports; but a } \\
\text { substantial part of the } R \& D \text { expenditure's effect } \\
\text { on exports has been found to be delayed. }\end{array}$ \\
\hline $\begin{array}{l}\text { Bojnec and Ferto } \\
\text { (2011) }\end{array}$ & $\begin{array}{l}1995-2003 \\
18 \text { OECD countries }\end{array}$ & Panel data analysis & $\begin{array}{l}\text { The study shows that there is a positive } \\
\text { relationship between } R \text { \& } D \text { expenditure and } \\
\text { manufacturing exports. The results reject the } \\
\text { non-linear relationship between R\&D and } \\
\text { manufacturing exports. }\end{array}$ \\
\hline $\begin{array}{l}\text { Özer and Çiftçi } \\
(2009)\end{array}$ & $\begin{array}{l}1993-2005 \\
19 \text { OECD countries }\end{array}$ & $\begin{array}{l}\text { Advanced panel data } \\
\text { analysis }\end{array}$ & $\begin{array}{l}\text { The findings of the study show that there is a } \\
\text { positive relationship between R \& D expenditures } \\
\text { and exports. In addition, the cross-sectional } \\
\text { effect coefficients of G7 countries are high and } \\
\text { positive. }\end{array}$ \\
\hline $\begin{array}{l}\text { Braunerhjelm } \\
\text { and Thulin (2008) }\end{array}$ & $\begin{array}{l}\text { 1981-1999 } \\
19 \text { OECD countries }\end{array}$ & $\begin{array}{l}\text { Panel data analysis } \\
\text { (fixed effects estimation } \\
\text { method) }\end{array}$ & $\begin{array}{l}\text { The results showed that } R \& D \text { expenditures } \\
\text { positively affected exports of high technology } \\
\text { products. The results show that a } 1 \% \text { increase in } \\
R \& D \text { expenditures leads to a } 3 \% \text { increase in } \\
\text { high tech exports. }\end{array}$ \\
\hline $\begin{array}{l}\text { Landesmann and } \\
\text { Pfaffermayr } \\
\text { (1997) }\end{array}$ & $\begin{array}{l}1967-1987 \\
7 \text { OECD countries }\end{array}$ & $\begin{array}{l}\text { AIDS-Almost Ideal Demand } \\
\text { System }\end{array}$ & $\begin{array}{l}\text { The study concluded that R \& D expenditures in } \\
\text { the United States, Great Britain and Japan } \\
\text { affected exports positively. However, in Germany } \\
\text { and France it has been found that there is a } \\
\text { negative relationship between R \& D } \\
\text { expenditures and exports. }\end{array}$ \\
\hline
\end{tabular}

\section{DATA, EMPIRICAL MODEL AND METHODOLOGY}

\subsection{Data and Empirical Model}

This paper examines relationship between the two variables for 16 OECD countries (Austria, Belgium, Canada, Finland, France, Germany, Ireland, Italy, Japan, Netherlands, Poland, Portugal, Spain, Turkey, United Kingdom and United States) from 2000 to 2015 are selected as there search samples. In this study, some OECD countries have been included in the analysis due to data constraints. The data for this study is measured annually. Table 2 gives the data used for the empirical analysis in this study.

\section{Table 2: Definitions and Descriptions of the Variables}

\begin{tabular}{|l|l|l|l|}
\hline Variable & Symbol & Description & Data Source \\
\hline $\begin{array}{l}\text { Natural logarithms of research } \\
\text { development expenditure }\end{array}$ & Inrd & $\begin{array}{l}\text { R\&D expenditures } \\
\text { (\% of GDP) }\end{array}$ & $\begin{array}{l}\text { OECD, OECD Science, Technology and } \\
\text { R \& D Statistics, 2018 }\end{array}$ \\
\hline Natural logarithms of export & Inexp & $\begin{array}{l}\text { Exports of goods and } \\
\text { services (\% of GDP) }\end{array}$ & $\begin{array}{l}\text { WB, World Development Indicators, } \\
2018\end{array}$ \\
\hline
\end{tabular}

The model used in the analysis is shown in Equation 1.

$\ln \exp _{i t}=\beta_{0 i}+\beta_{1 i} \ln r d_{i t}+\varepsilon_{i t}$

where, $\exp _{i t}$ is the export in i country at the time $t, \mathrm{rd}_{\mathrm{it}}$ is the research and development expenditure as proxy research development activities in $\mathrm{i}$ country at the time $\mathrm{t}, \beta_{0}$ is a constant term, $\beta_{1}$ is slope coefficients of the model, $\varepsilon_{\mathrm{t}}$ is an error term. 


\subsection{ECONOMETRIC METHODOLOGY}

\subsubsection{Unit Root Tests}

One of the methods to be applied in this study is the cointegration analysis. In order to be able to do the cointegration analysis, the stationary of the variables considered should be determined. The unit root examination is conducted using four unit root tests; namely, the Levin, Li and Chu; Im, Pesaran and Shin W-stat; Fisher-ADF and Fisher-PP.

We first use the panel ADF (LLC) test proposed by Levin, Lin and Chu (2002) by assuming the homogeneity in the dynamics of the autoregressive coefficients for all panel units. Secondly, we use Im, Pesaran and Shin W-stat (IPS) test proposed by $\mathrm{Im}$, Peseran and Shin (2003). IPS test is used to research the existence of unit root of panel data when powerful tests are needed for the small set of observations (Şen et al., 2014: 20). In addition, we use the nonparametrictests of including the ADF-Fisher Chi-square and the PP-Fisher Chi-square tests, take into account of the heterogeneity across units proposed by Maddala and Wu (1999) and Choi (2001) (Gozgor et al., 2018: 31).

For all the tests considered in the analysis, the null hypothesis implies that time series contain unit root and the alternative hypothesis states that time series are stationary.

\subsubsection{Co-Integration Tests}

In the following level, the presence of a long-run relationship between the factors is analyzed. Co-integration tests are used for this. This study uses two co-integration techniques; namely, Pedroni panel co-integration Test (1999) and Kao panel cointegration tests (1999).

In the Pedroni cointegration test, seven different tests were presented to show the effects of in section (within) and crosssectional (between) in panel and these tests are divided into two different categories. The first category contains four tests pooled within the dimension, the second category contains three other tests in the "between" dimension. The proposed within test statistics are: The panel v-statistics, panel rho-statistics, panel PP-statistics, panel augmented Dickey-Fuller (ADF)-statistics; the proposed between test statistics are group rho-statistics, group PP-statistics and group ADF-statistics.

For the within-dimension statistics the null hypothesis of no cointegration for the panel cointegration test is $H_{0}=\gamma_{i}=1$

for all $\mathrm{i}$, versus the alternative hypothesis $H_{1}=\gamma_{i}=\gamma<1$ for all $\mathrm{i}$, so that it presumes a common value for $\gamma_{i}=\gamma$. By contrast, for the between-dimensions statistics the null of no cointegration for the panel cointegration test is $H_{0}=\gamma_{i}=1$ for all $\mathrm{i}$, versus the alternative hypothesis $H_{1}=\gamma_{i}=\gamma<1$ for all $\mathrm{i}$, so that it does not presumes a common value for $\gamma_{i}=\gamma$ under the alternative hypothesis (Pedroni, 1999: 657).

The other cointegration test to be used in the study is Kao (1999) cointegration test. This test presents a cointegration test for panel data analysis using Dickey Fuller (DF) and Augmented Dickey Fuller (ADF) tests. According to this test, the null hypothesis states that there is no cointegration between the series and the alternative hypothesis is that it is cointegration between the series (Tatoğlu, 2012: 233).

\subsubsection{Panel FMOLS and DOLS}

The next step is to estimate the cointegration parameters after the cointegration relation is established in this study. Two different methods have been used in this study, namely panel FMOLS (Fully Modified Ordinary Least Square) test and Panel DOLS (Dynamic Ordinary Least Square) test developed by Pedroni $(2000,2001)$. While the FMOLS method corrects deviations in standard fixed effect estimators (such as autocorrelation, varying variance), the DOLS method is a method with the ability to remove deviations from the static regression (especially due to endogeneity problems), including dynamic elements of the model. The FMOLS method, which permits a significant degree of heterogeneity between individual cross sections of the Pedroni, accounts for the existence of a possible correlation between the constant term and the error term and the differences between the independent variables(Gülmez, 2015: 24).

Panel FMOLS estimator is expressed as $\hat{\beta}_{G F M}^{*}=N^{-1} \sum_{i=1}^{N} \beta_{F M i}^{*} \cdot \beta_{F M i}^{*}$ is derived from the Panel FMOLS estimate for each country in equation (1). Panel DOLS estimator, the model in Eq. (2) is obtained by using the ECL estimates for each country. 
$\ln \exp _{i t}=\beta_{0 i}+\beta_{1 i} \ln r d_{i t}+\sum_{k=-K_{i i}}^{K_{i i}} \alpha_{i k} \Delta \ln r d_{i t}+\varepsilon_{i t}$

where $-\mathrm{Ki}$ and Ki indicate the number of leads and lags. The Panel DOLS estimator is written as $\hat{\beta}_{G D}^{*}=N^{-1} \sum_{i=1}^{N} \beta_{D i}^{*}$ olarak yazılır. $\beta_{D i}^{*}$ is obtained from the prediction of equation (2) (Şahbaz et al., 2014: 54).

\section{EMPIRICAL FINDINGS}

\subsection{Unit Root Tests}

Before modeling, the LLC, IPS Fisher-ADF and Fisher-PP tests are applied to judge whether the two variables, Inrd and Inexp have the unit root or not. The results of unit root tests of R\&D expenditures and export variables are shown in Table 3.

Table 3: Results of the Panel Unit Root Tests

\begin{tabular}{|l|l|l|l|l|}
\hline Variables & LLC & IPS & Fisher-ADF & Fisher-PP \\
\hline \multirow{2}{*}{ Inrd } & -0.99310 & 1.97568 & 20.0382 & 14.0059 \\
& $(0.1603)$ & $(0.9759)$ & $(0.9506)$ & $(0.9976)$ \\
\hline \multirow{2}{*}{$\Delta$ Inrd } & -6.22512 & -5.78136 & 94.4706 & 114.127 \\
& $(0.0000)$ & $(0.0000)$ & $(0.0000)$ & $(0.0000)$ \\
\hline \multirow{2}{*}{ Inexp } & -1.10374 & 0.92226 & 27.7146 & 28.9099 \\
& $(0.1349)$ & $(0.8218)$ & $(0.6834)$ & $(0.6237)$ \\
\hline \multirow{2}{*}{$\Delta$ Inexp } & -13.1292 & -9.21403 & 135.749 & 170.450 \\
& $(0.0000)$ & $(0.0000)$ & $(0.0000)$ & $(0.0000)$ \\
\hline
\end{tabular}

Note: The number of lag is based on the Akaike Information Criteria (AIC). Maximum number of lag is 3.

The deterministic specification of the tests is fixed. Probability values are shown in brackets. As shown in Table 3 , the tested statistics reject the null hypothesis, indicating the variables are stationary at the level and contain a panel unit root. This means that these variables are integrated of order one I(1). All test results related to variables included in the analysis are consistent with each other.

\subsection{Co-Integration Tests}

Based on the same single order of the variables, whether co-integration exists between the variables or not is further tested. Then, the two variables are tested by the cointegration methods of Pedroni and Kao. Co-integration test results are shown in Table 4.

Table 4: Cointegration Test Results

\begin{tabular}{|c|c|c|c|c|}
\hline \multicolumn{5}{|c|}{$\ln \exp _{i t}=\alpha_{i t}+\beta \ln r d_{i t}+u_{i t}$} \\
\hline \multicolumn{5}{|c|}{ Pedroni Panel CointegrationTest Results } \\
\hline \multicolumn{5}{|l|}{ (Within-Dimension) } \\
\hline & Stat & Prob. & WeightedStatistic & Prob. \\
\hline Panel v-Statistic & 0.304406 & 0.3804 & -0.158143 & 0.5628 \\
\hline Panel rho-Statistic & -0.680187 & 0.2482 & -0.953923 & 0.1701 \\
\hline Panel PP-Statistic & -1.988563 & 0.0234 & -2.697701 & 0.0035 \\
\hline Panel ADF-Statistic & -1.939772 & 0.0262 & -2.862427 & 0.0021 \\
\hline \multicolumn{5}{|l|}{ (Between-Dimension) } \\
\hline & Stat & Prob & & \\
\hline Group rho-Statistic & 0.503838 & 0.6928 & & \\
\hline Group PP-Statistic & -3.514383 & 0.0002 & & \\
\hline Group ADF-Statistic & -2.638003 & 0.0042 & & \\
\hline \multicolumn{5}{|c|}{ Kao Panel CointegrationTest Results } \\
\hline & t-stat & Prob & & \\
\hline ADF & -1.933636 & 0.0266 & & \\
\hline Residual variance & 0.004830 & & & \\
\hline HAC variance & 0.004790 & & & \\
\hline
\end{tabular}


According to the Pedroni cointegration test results, four of the seven test statistics reject the null hypothesis; that is, there is no cointegration relationship. Therefore, long-term cointegration relationships exist between Inrd and Inexp. EngleGranger based Kao test was applied to support the results of Pedroni panel cointegration test. According to the Kao cointegration test result, the null hypothesis that cointegration does not exist is rejected as a result of the $p$ value becoming significant, and the alternative hypothesis which advocates cointegration is accepted.

\subsection{Panel FMOLS and DOLS}

In the study, Panel FMOLS and DOLS estimators were used to obtain long run coefficients after the cointegration relation was detected. The elasticity coefficients for the Inexp and Inrd variables are shown in Table 5.

\section{Table 5: Long-Run Coefficients}

\begin{tabular}{|l|l|l|l|l|l|}
\hline Dependent Variable: Inexp & \multicolumn{4}{|l|}{} \\
\hline Method(s) & $\begin{array}{l}\text { Independent } \\
\text { Variable }\end{array}$ & Cofficient & Std. Error & t-stat & Prob \\
\hline Panel FMOLS & Inrd & 0.446586 & 0.074299 & 6.010693 & 0.0000 \\
Panel DOLS & Inrd & 0.429436 & 0.083444 & 5.146410 & 0.0000 \\
\hline
\end{tabular}

As can be seen from Table 5, both Panel FMOLS and Panel DOLS test results show that the sign of research and development expenditure is positively and statistically significant in line with the theory when evaluated on a panel basis. According to the Panel FMOLS test results, a $1 \%$ increase in research and development expenditure leads to a $0.45 \%$ increase in exports. Similarly, according to Panel DOLS test results, $1 \%$ increase in research and development expenditure increases exports by $0.43 \%$.

\section{CONCLUSION}

$R$ \& D activities, which are important in increasing export performance, help countries to gain competitive power and thus to achieve economic growth. There is a comprehensive theoretical literature on the relationship between $R \& D$ activities and exports. The vast majority of studies have reached the conclusion that $R \& D$ activities have increased exports.

In this study, the impact of R \& D activities on exports was analyzed for 16 OECD countries using data for the period 20002015. Pedroni (1999) and Kao (1999) panel cointegration tests were used to test whether there is a long-term relationship between variables in the study. As a result of the cointegration tests, it is concluded that there is a long-run relationship between R \& D expenditures and exports. Panel FMOLS and Panel DOLS tests developed by Pedroni $(2000,2001)$ is applied to determine the magnitude and direction of the coefficients of the variables used in the study. The panel FMOLS test result shows that $1 \%$ increase in $R \& D$ expenditure increased exports by $0.45 \%$ while Panel DOLS test result shows that exports increased by $0.43 \%$. In other words, the evidence that $R \& D$ expenditures, which is a demonstration of $R \& D$ activities, positively affects exports has been reached. Results obtained in the study are consistent with existing findings in the literature.

According to the results obtained, it is necessary for policy makers to consider this effect of $R$ \& $D$ activities within the export incentive instruments. Hence, increasing the share of $R \& D$ expenditure in the budget has special importance in order to increase the competitiveness of the countries. For the future studies, the literature may contribute to the studies on the effect of sector-based R \& D activities on exports.

\section{REFERENCES}

Akiş, E. (2015). Innovation and competitive power. Procedia - Social and Behavioral Sciences 195, 1311-1320.

Bojnec, S., Ferto I. (2011). Impacts of researchand development on manufacturing trade. Proceedings of Rijeka Faculty of Economics, 29 (1), 65-88.

Braunerhjelm, P., Thulin, P. (2006). Can countries create comparative advantages?. Centre of Excellence for Studies in Science and Innovation (CESIS), Electronic Working Paper Series, Working Paper No. 61.

Choi, I. (2001). Unit root tests for panel data. Journal of International Money and Finance, 20, 249-272.

Çetin, R. (2016). Yeni sanayileşen ülkelerde Ar-Ge harcamaları ve yüksek teknoloji ürünü ihracatı arasındaki ilişkinin panel veri analizi yöntemi ile incelenmesi. İktisat Fakültesi Mecmuası, 66 (2), 30-43.

Esteve-Pérez, S., Rodríguez, D. (2013). The dynamics of exports and R\&D in SMEs. Small Business Economics, 41(1), 219-240.

Girma, S., Görg, H., Hanley, A. (2008). R\&D and exporting: a comparison of British and Irish firms. Review of World Economics, 144 (4), 750773. 
Gozgor, G., Lu, C. K. M., Lau, Z. (2018). Energy consumption and economic growth: new evidence from the OECD countries. Energy, 153, 2734.

Göçer, İ. (2013a). Ar-Ge harcamalarının yüksek teknolojili ürün ihracatı, dış ticaret dengesi ve ihracat üzerindeki etkileri. Maliye Dergisi, 165, 215-250.

Göçer, i. (2013b). Teknolojik ilerlemenin belirleyicileri: NIC ülkeleri için panel eşbütünlesme ve panel nedensellik analizleri. Maliye Finans Yazıları, 100, 116-141.

Gülmez, A. (2015). OECD ülkelerinde ekonomik büyüme ve hava kirliliği ilişkisi: panel veri analizi. Kastamonu Üniversitesi i̇ktisadi ve İdari Bilimler Fakültesi Dergisi, 9, 18-29.

Güzel, S. (2009). Ar-Ge harcamaları ve vergi teşvikleri: belirli ülkeler karşısında Türkiye'nin durumu. Eskişehir Osmangazi Üniversitesi iïBF Dergisi, 4 (2), 29-48.

Im, K. S., Pesaran, M. H., Shin, Y. (2003). Testing for unit roots in heterogeneous panels. Journal of Econometrics, 115(1), 53-74.

Kao, C. (1999). Spurious regression and residual-based tests for cointegration in panel data. Journal of Econometrics, $90,1-44$.

Kılıç, C., Bayar Y., Özekicioğlu H. (2014). Araştırma geliştirme harcamalarının yüksek teknoloji ürün ihracatı üzerindeki etkisi: G-8 ülkeleri için bir panel veri analizi. Erciyes Üniversitesi İktisadi ve İdari Bilimler Fakültesi Dergisi, 44, 115-130.

Landesmann, M., Pfaffermayr, M. (1997). Technological competition and trade performance. Applied Economics, 29 (2), $179-196$.

Levin, A. , Lin, C. F., Chu, C. (2002). Unit root tests in panel data: asymptotic and finite sample properties. Journal of Econometrics, 108 (1), $1-24$.

Maddala, G. S., Wu, S. (1999). A comparative study of unit root tests with panel data and a new simple test. Oxford Bulletin of Economics and Statistics, 61 (S1), 631-652.

Neves, A., Teixeira, A. A. C., Silva, S. T. (2016). Exports- R \& D investment complementarity and economic performance of firms located in Portugal. Investigación Económica, 75(295), 125-156.

Özer, M., Çiftçi, N. (2009). Ar-Ge harcamaları ve ihracat ilişkisi: OECD ülkeleri panel veri analizi. Dumlupınar Üniversitesi Sosyal Bilimler Dergisi, 23, 39-49.

Özkan, G., Yılmaz, H. (2017). Ar-Ge harcamalarının yüksek teknoloji ürün ihracatı ve kişi başı gelir üzerindeki etkileri: 12 AB ülkesi ve Türkiye için uygulama (1996-2015). Bilgi Ekonomisi ve Yönetimi Dergisi, 12(1), 1-12.

Pedroni, P. (1999). Critical values for cointegration tests in heterogeneous panels with multiple regressors. Oxford Bulletin of Economics and Statistics, 61(S1), 653-670.

Pedroni, P. (2000). Fully-modified OLS for heterogeneous cointegrated panels. Advances in Econometrics, 15, 93-130.

Pedroni, P. (2001). Purchasing power parity tests in cointegrated panels. Review of Economics and Statistics, 83, $727-731$.

Pradeep, V., Bhattacharya, M., Chen J. R. (2017). Spillover effects of research and development, exports and foreign investment on productivity: empirical evidence from Indian manufacturing. Journal of South Asian Development, 12(1), 18-41.

Sandu, S., Ciocanel, B. (2014). Impact of R\&D and innovation on high-tech export. Procedia Economics and Finance, 15, 80-90.

Svensson, R. (2008). Growth through research and development. Swedish Government Agency for Innovation Systems Report, https://www.vinnova.se/contentassets/409b49574a5440c884eac129b dd65e8c/vr-08-19.pdf

Sungur, O., Aydın H. İ., Eren, M. V. (2016). Türkiye'de Ar-Ge, inovasyon, ihracat ve ekonomik büyüme arasındaki ilişki: asimetrik nedensellik analizi. Süleyman Demirel Üniversitesi İktisadi ve İdari Bilimler Fakültesi Dergisi, 21(1), 173-192.

Şahbaz, A., Yanar, R., Adıgüzel, U. (2014). Ar-Ge harcamaları ve ileri teknoloji mal ihracatı ilişkisi: panel nedensellik analizi. Ç.Ü. Sosyal Bilimler Enstitüsü Dergisi, 23(1), 47-60.

Şen, A., Şentürk M., Özkan, G., Ducan, E. (2014). External determinants of economic growth in developing countries: panel data analysis. Marmara Üniversitesi İ.i.B. Dergisi, 36(1), 15-28.

Tatoğlu, F. Y. (2012). İleri panel veri analizi stata uygulamalı. Beta Basım Yayım Dağıtım A.Ş., İstanbul.

Türker, O. (2018). G-7 ülkelerinde Ar-Ge harcamalarının ihracat üzerindeki etkisi. 12-14 Nisan, Nevşehir IERFM Uluslararası Ekonomi Araştırmaları ve Finansal Piyasalar Kongresi Bildiri Kitabı, 351-363.

Uzay, N., Demir, M., Yıldırım E. (2012). İhracat performansı açısından teknolojik yeniliğin önemi: Türkiye imalat sanayi örneği. Doğuş Üniversitesi Dergisi, 13(1), 147-160.

Yıldırım, E., Kesikoğlu F. (2012). Ar-Ge harcamaları ile ihracat arasındaki nedensellik ilişkileri: Türkiye örneğinde panel nedensellik testi kanıtları. Marmara Üniversitesi iïBF Dergisi, 32 (1), 165-180.

Yüksel, S. (2017). The impacts of research and development expenses on export and economic growth. International Business and Accounting Research Journal, 1(1), 1-8. 